\title{
PEMBUKTIAN FENOMENA EARNING MANAGEMENT PADA PERBANKAN SYARIAH: ANALISIS LABA RIIL DAN LABA AKRUAL
}

\author{
Ari Dewi Cahyati \\ Fakultas Ekonomi Universitas Islam 45 Bekasi \\ Jl. Cut Meutia Bekasi \\ Email: aridewi71@yahoo.co.id
}

Abstract

The aim of this research is to test whether there is any earning management action at shariah banking or not'. Earning management is measured by real earning management and accrual earning management. Real earning management is indicated in the proxy of CFO abnormal, and then accrual earning management is indicated in accrual discretionary. Secondary data from Indonesia Bank web is used in this research. This study will provide useful information to the users of financial statements whether there are any actions of earnings management in Islamic banks, as a result that users of financial statements will be more careful in reading financial statements. The indication of earnings management in banking also requires attention BI as a regulator of banking in Indonesia. The results show that shariah banking doesnot carry out accrual earning management that is indicated in mean value DA of 0.00. It is found mean values for abnormal cash flow of -0.025 in real earnings management of Islamic banks which also indicates earnings management is done by minimizing the profits. Meanwhile, âl has a positive value 0.283 and sig 0.564. This indicates that the suspect Islamic bank (poor performance) did not conduct real earnings management by manipulating the cash flow statement

Keywords: earning management riil, earning management accrual, and shariah banking 
Abstrak

Tujuan dari penelitian ini adalah menguji apakah terdapat tindakan earning management pada perbankan syariah. Tindakan earningmanagement ini diukur dengan earning management riil dan earning management accrual. Manajemen laba riil diindikasikan dengan proksi, yaitu abnormal CFO,sedangkan manajemen laba akrual diindikasikan dengan discretionary accrual. Data penelitian ini merupakan data sekunder yang diperoleh dari web Bank Indonesia. Manfaat penelitian ini memberikan informasi kepada pengguna laporan keuangan apakah terdapat tindakan Manajemen laba di bank syariah sehingga pengguna laporan keuangan dapat lebih teliti dalam membaca laporan keuangan. Adanya indikasi manajemen laba diperbankan juga perlu mendapat perhatian BI sebagai penyusun regulasi yang terkait dengan perbankan di Indonesia. Berdasarkan hasil penelitian ditemukan bahwa bank syariah tidak melakukan earning management accrual yang diindikasikan dengan nilai mean DA 0.00. Berdasarkan hasil olah data manajemen laba riil bank syariah ditemukan nilai mean untuk abnormal cash flow -0.025 yang juga mengindikasikan bahwa manajemen laba dilakukan dengan cara memperkecil laba. Sedangkan $\beta 1$ bernilai positif 0.283 dan sig 0.564 . Hal ini mengindikasikan bahwa bank syariah suspect (kinerja buruk) tidak melakukan manajemen laba riil dengan upaya memanipulasi laporan arus kas.

Kata kunci: manajemen laba riil, manajemen laba akrual, perbankan syariah

\section{PENDAHULUAN}

Laporan keuangan merupakan alat pertanggungjawaban pihak manajemen kepada pemilik. PSAK 1 (revisi 2009) menyatakan bahwa laporan keuangan terdiri dari laporanlaba rugi komprehensif, laporan perubahan ekuitas, laporan posisi keuangan, laporan arus kas, laporan posisi keuangan komparatif yang disajikan secara retrospektif ketika perusahaan menerapkan kebijakan akuntansi yang bersifat retrospektif. Namun dari berbagai laporan keuangan tersebut yang paling banyak menjadi perhatian investor, kreditur dalam proses pengambilan keputusan adalah laporan laba rugi. Hal tersebut mendorong dysfunctional pihak manajemen untuk melakukan manipulasi terhadap laporan laba rugi. Agency theory menyatakan bahwa perusahaan merupakan titik temu antara pihak agen dan pihak prinsipal di mana kedua berada dalam situasi konflik kepentingan. Pihak agent (manajemen) yang lebih memahami tentang kondisi perusahaan akan cenderung memaksimalkan utilitasnya dengan memanipulasi laporan keuangan yaitu dengan melakukan earning management/manajemen laba.

Bank syariah selaku entitas bisnis juga menyusun laporan keuangan sebagai pertanggungjawaban pihak manajemen kepada pemilik. Kerangka dasar penyusunan laporan keuangan syariah menyatakan bahwa tujuan penyusunan laporan keuangan 
syariah adalah (1) membantu mencapai keadilan sosio ekonomi (Al Falah) (2) mengenal sepenuhnya kewajiban kepada Tuhan, masyarakat individu sehubungan dengan pihak-pihak yang terkait dengan aktivitas ekonomi yaitu akuntan, auditor, manajer, pemilik, pemerintah dan sebagainya sebagai bentuk ibadah.Menurut Padmantyo (2010:54), tujuan manajemen keuangan syariah adalah pertanggungjawaban (accountability), baik pertanggungjawaban terhadap Allah, pihak-pihak yang berhak atas perusahaan, maupun alam. Pihak-pihak yang berhak atas perusahaan adalah pengguna laporan keuangan diantaranya adalah pemilik dana, pihakpihak yang memanfaatkan dan menerima penyaluran dana, pembayar zakat, pemegang saham, otoritas pengawasan, Bank Indonesia, pemerintah, lembaga penjamin simpanan dan masyarakat. Oleh karena itu bank syariah sebagai lembaga yang berdasarkan prinsip Islam tidak diperkenankan untuk memanipulasi atau merekayasa laba dalam membuat laporan keuangan.

Penelitian Zahara dan Siregar (2009) menggunakan Proksi accrual discretionary yang disesuaikan untuk perbankan sebagai ukuran manajemen laba meneliti pengaruh Rasio Camel terhadap earning management. Hasil penelitian tidak ada manajemen laba pada bank syariah dan rasio Camel kecuali NPM (Net profit Margin) tidak berpengaruh signifikan terhadap earning management. Padmantyo (2010) menggunakan proksi model Jones yang dimodifikasi sebagai ukuran manajemen laba meneliti earning management pada Bank Syariah Mandiri dan Bank Muamalat. Hasil Penelitian mengindikasikan total acrrual yang positif selama 4 tahun dan negatif selama 1 tahun sehingga terdapat manajemen laba pada laporan keuangan Bank Syariah Mandiri dan Bank Muamalat Indonesia selama 4 tahun. Faradila (2014) menggunakan ukuran model Jones yang dimodifikasi sebagai ukuran manajemen laba meneliti apakah terdapat earning management pada perbankan syariah dan hasil penelitiannya menyatakan terdapat earning management pada perbankan syariah yang ditandai dengan rata-rata discretionary accrual negative pada tahun 2011 dan 2012.

Penelitian diatas umumnya menggunakan pendekatan aggregate accrual untuk mengukur tindakan manajemen laba. Pendekatan tersebut memisahkan total akrual menjadi komponen non discretionary accrual (komponen akrual diluar kebijakan manajemen) dan discretionary accrual (komponen akrual yang berada dalam kebijakan manajemen (Trisnawati, dkk., 2010). Salah satu kelebihan pendekatan aggregate accrualadalah pendekatan tersebut berpotensi untuk dapat mengungkap cara-cara untuk menaikkan atau menurunkan laba, karena cara-cara tersebut kurang mendapat perhatian untuk diketahui oleh pihak luar (Gumanti, 2000 dalam Trisnawati, dkk., 2010). Akan tetapi penggunaan model discretionary accrualn(aggregate accrual) menuai banyak kritikan dari para peneliti diantaranya Gomez, et al. (1999) dalam Trisnawati, 2010). Mereka beralasan bahwa pada model-model tersebut (aggregate accrual/discretionary accrual) tidak mengindahkan hubungan antara arus kas dan akrual, sehingga beberapa nondiscretionary 
accrual telah salah klasifikasi dan diklasifikasikan sebagai discretionary. Kesalahan tersebut berakibat pada kesalahan spesifikasi dalam model-model tersebut (Trisnawati, dkk., 2010).

Roychodhury (2006) dalam Trisnawati (2010) menyatakan earning management yang dilakukan hanya mendasarkan pada pengaturan akrual saja mengkin menjadi tidak valid, sehingga penting untuk memahami manipulasi laba riil. Penelitian ini mengukur manajamen laba di perbankan syariah dengan pendekatan manipulasi laba riil dan laba acrual. Manipulasi laba riil diukurdengan proksi abnormal operating cash flow, abnormal discretionary expenses dan abnormal production cost dan laba akrual dengan model Healy (1985) dan Jones (1991) yang disesuaikan sesuai dengan karakteristik perbankan.

Rumusan masalah pada penelitian ini adalah"Apakah terdapat praktik manajemen laba pada perbankan syariah dengan melakukan manipulasi laba riil?" dan "Apakah terdapat praktik manajemen laba pada perbankan syariah dengan memanipulasi laba akrual?"

Berdasarkan rumusan masalah yang telah diuraikan, maka peneliti membatasi penelitian yang dilakukan untuk mengetahui ada atau tidaknya manajemen laba pada perbankan bank syariah sebagai berikut:Pertama, laporan keuangan yang digunakan selama3 tahun yaitu tahun 2010-2012 untuk membuktikan kinerja bank syariah. Kedua, Penggunaan manajemen laba yang dilakukan oleh bank syariah berdasarkan pembuktian model Jones (1991) yang disesuaiakan untuk perbankan dan untuk mengukur manajemen laba riil hanya menggunakan model abnormal cash flow (Roydhuchory, 2006).

Tujuan penelitian iniuntuk mengetahui praktek earning managementpada perbankan syariah dengan menggunakan pendekataan manipulasi laba riil dan laba akrual.

Hasil penelitian ini dapat bermanfaat oleh: Pertama, bagi peneliti selanjutnya, penelitian ini diharapkan bisa dijadikan referensi untuk riset yang akan datang. Kedua, bagi akademika, penelitian ini diharapkan dapat menjadi referensi dan memberikan sumbangan konseptual dalam rangka mengembangkan ilmu pengetahuan untuk perkembangan dan kemajuan dunia pendidikan. Ketiga, bagi pengembangan ilmu akuntansi, penelitian ini diharapkan dapat memperkaya materi pembelajaran terkait dengan manajemen laba serta perbankan bank syariah. Keempat, bagi para pemakai laporan keuangan, penelitian ini diharapkan dapat memberikan manfaat dalam memahami manajemen laba sehingga dapat mengetahui praktik manajemen laba.

\section{TINJAUAN PUSTAKA DAN PENGAMBANGAN HIPOTESIS}

\section{Agency Theory}

Dalam teori keagenan (agency theory) misalnya terdapat 2 (dua) pihak yang melakukan kontrak yaitu agent (pihak manajemen) dan principal (dalam hal ini 
bisa pemilik atau pemberi pinjaman), Wolk dan tearney, hal. 89 (1996) menjelaskan dalam agency theory perusahaan digambarkan sebagai lokus (titik temu) hubungan keagenan antara pemilik perusahaan (principal) dan manajemen perusahaan (agent). Hubungan antara agent dan principal biasannya dalam situasi informasi asimetri atau ketidakseimbangan informasi. Dimana pihak manajemen mempunyai informasi yang lebih banyak dibandingkan dengan prinsipal.

Dalam teori agensi disebutkan bahwa masing-masing pihak yaitu agent dan principalberusaha untuk memaksimalkan kepentingan dirinya sendiri, sehingga menimbulkan konflik kepentingan diantara principal dan agent (Scott, 1997:240). Konflik kepentingan timbul karena: (a) Manajemen berkeinginan untuk meningkatkan kesejahteraan sedangkan pihak pemilik berkeinginan meningkatkan kekayaan; (b) Manajemen berusaha untuk mendapatkan kredit sebesar-besarnya dengan bunga yang rendah sedangkan pihak kreditor hanya akan memberikan kredit sebatas kemampuan perusahaan; (c) Manajemen berusaha membayar pajak sekecil mungkin sedangkan pemerintah ingin memungut pajak setinggi mungkin.

\section{Manajemen Laba}

Konsep manajemen laba menggunakan pendekatan teori keagenan. Teori agensi berfokus pada dua individu yaitu prinsipal dan agen yang masing-masing pihak yaitu agen dan prinsipal berusaha untuk memaksimalkan kepentingan dirinya sendiri, sehingga menimbulkan konflik kepentingan di antara prinsipal dan agen (Scott, 1997:240).

Earnings management merupakan intervensi dari pihak manajemen untuk mengatur laba yaitu dengan menaikkan atau menurunkan laba akuntansi dengan memanfaatkan atau kelonggaran penggunaan metode dan prosedur akuntansi. Karena standar akuntansi memperbolehkan perusahaan untuk memilih metode akuntansi.

\section{Motivasi Manajemen Laba}

Beberapa motivasi yang mendorong earnings management antara lain informasi earnings atau laba banyak digunakan oleh para investor dan kreditur dalam membuat keputusan investasi atau pemberian kredit. (Watts, Zimmerman 1986 dalam Pramudji, Trihartati, 2010) menyatakan bahwa motivasi manajemen laba antara lain: 1) Bonus plan hypothesis di mana laba juga sebagai dasar dalam pemberian bonus kepada karyawan. Misalnya pada saat keuntungan dijadikan patokan dalam pemberian bonus, maka akan menciptakan dorongan kepada para manajer untuk memanajemen data keuangan agar dapat menerima bonus seperti yang diinginkan 2) Debt (equity) hypothesis menegaskan bahwa perusahaan dengan rasio debt to equity ratio lebih besar, cenderung untuk memilih prosedurprosedur akuntansi yang dapat menaikkan labanya 3) Political cost hypothesis, 
perusahaan cenderung memilih metode akuntansi yang dapat menurunkan laba bersih yang dilaporkan. Manajamen laba yang dilakukan manajer akan menurunkan kualitas laba. Manajemen laba akan membuat kemampuan laba untuk memprediksi laba masa depan menjadi berkurang.

\section{Teknik Manajemen Laba}

Teknik dan pola manajemen laba menurut (Setiawati dan Na'im, 2000) dalam Pramudji, Trihartati, 2010) dapat dilakukan dengan cara sebagai berikut:

\section{Memanfaatkan Peluang untuk Membuat Estimasi Akuntansi}

Manajemen dapat mempengaruhi laba melalui perkiraan terhadap estimasi akuntansi antara lain estimasi tingkat piutang tak tertagih, estimasi kurun waktu depresiasi asset tetap atau amortisasi asset tidak berwujud, estimasi biaya garansi, dan sebagainya.

\section{Mengubah Metode Akuntansi}

Manajemen laba dapat dilakukan dengan mengubah metode akuntansi yang digunakan untuk mencatat suatu transaksi. Contoh mengubah depresiasi asset tetap dari metode jumlah angka tahun ke metode garis lurus.

\section{Menggeser Periode Biaya atau Pendapatan}

Manajemen laba dapat dilakukan dengan menggeser periode atau pendapatan. Contohnya dengan mempercepat atau menunda pengeluaran untuk penelitian sampai pada periode akuntansi periode berikutnya, mempercepat atau menunda pengeluaran promosi sampai periode berikutnya, mempercepat atau menunda pengiriman produk ke pelanggan, mengatur penjualan aset tetap perusahaan.

\section{Manajemen Laba Riil}

Manajemen laba riil adalah tindakan-tindakan manajemen yang menyimpang dari praktik bisnis yang normal yang dilakukan dengan tujuan utama untuk mencapai target laba (Roychowdhury, 2006; Cohen dan Zarowin, 2010 dalam Trisnawati dkk., 2011). Manajemen laba riil dapat dilakukan dengan 3 (tiga) cara yaitu:

\section{Manipulasi Penjualan}

Manipulasi penjualan merupakan usaha untuk meningkatkan penjualan secara temporer dalam periode tertentu dengan menawarkan diskon harga produk secara berlebihan atau memberikan persyaratan kredit yang lebih lunak. Strategi ini dapat meningkatkan volume penjualan dan laba periode saat ini, dengan mengasumsikan 
marginnya positif. Namunpemberian diskon harga dan syarat kredit yang lebih lunak akan menurunkan aliran kas periode saat ini.

\section{Penurunan Beban-Beban Diskresionari (Dicretionary Expenditures)}

Perusahaan dapat menurunkan discretionary expenditures seperti beban penelitian dan pengembangan, iklan, dan penjualan, adminstrasi, dan umum terutama dalam periode di mana pengeluaran tersebut tidak langsung menyebabkan pendapatan dan laba. Strategi ini dapat meningkatkan laba dan arus kas periode saat ini namun dengan resiko menurunkan arus kas periode mendatang.

\section{Produksi yang Berlebihan (Overproduction)}

Untuk meningkatkan laba, manajer perusahaan dapat memproduksi lebih banyak daripada yang diperlukan dengan asumsi bahwa tingkat produksi yang lebih tinggi akan menyebabkan biaya tetap per unit produk lebih rendah. Strategi ini dapat menurunkan kos barang terjual (cost of goods sold) dan meningkatkan laba operasi.

Ketiga cara manipulasi aktivitas riil di atas biasanya dilakukan oleh perusahaanperusahan dengan kinerja yang buruk sehingga tidak banyak memiliki akrual untuk dimanipulasi. Satu-satunya cara adalah dengan manipulasi aktivitas riil tersebut terutama untuk mencapai laba sedikit di atas nol. Dengan ketiga cara di atas perusahaanperusahaan yang diduga (suspect) melakukan manipulasi aktivitas riil akan mempunyai abnormal cash flow operations (CFO) dan abnormal production cost yang lebih besar dibandingkan perusahaan-perusahaan lain serta abnormal discretionary expenses yang lebih kecil.

Berdasarkan survei yang dilakukan oleh Graham, et al. (2005), (Roychowdhury, 2006 dalam trisnawati, 2011) menunjukkan para eksekutif keuangan lebih memilih untuk memanipulasi laba melalui aktivitas-aktivitas riil daripada aktivitas akrual. Hal ini disebabkan oleh: (1) Manipulasi akrual cenderung membuat para auditor atau regulator melakukan pemeriksaan dengan cepat daripada jika keputusankeputusan tentang aktivitas real atau produksi yang dibuat. Hal ini menunjukkan bahwa baik auditor ataupun regulator kurang memberikan perhatian terhadap aktivitas-aktivitas riil yang dimanipulasi oleh manajemen, sehingga manajemen memiliki kesempatan untuk memanfaatkan peluang ini dalam mencapai target laba. (2) Hanya bersandar pada manipulasi akrual saja akan membawa resiko karena pengelolaan laba dengan mengandalkan akrual diskresioner hanya dapat dilakukan pada akhir tahun. Akan tetapi, strategi ini menimbulkan resiko yaitu jika jumlah laba yang perlu dimanipulasi lebih besar daripada akrual diskresioner yang dapat digunakan manajer. Sehingga kemampuan manajer dalam memanipulasi laba terbatas, akibatnya target laba tidak dapat dicapai jika hanya mengunakan akrual diskresioner pada akhir tahun. Manajer dapat mengurangi resiko ini dengan memanipulasi aktivitas-aktivitas riil selama tahun berjalan (Wei Yu, 2008). 
Berdasarkan (Roychowdhury, 2006 dalam Subekti, Kee dan Ahmad, (2010): pengukuran manajemen laba riil menggunakan:

\section{Abnormal Cash Flow Operations (CFO)/Arus Kas Operasi Abnormal}

CFO abnormal adalah manipulasi laba yang dilakukan perusahaan melalui aliran operasi kas yang akan memiliki aliran kas lebih rendah daripada level normalnya. Etimasi nilai residu dari CFO merupakan nilai abnormal CFO.

\section{Abnormal Production Cost (PROD)/Biaya Kegiatan Produksi Abnormal}

Abnormal production cost adalah manajemen laba riil yang dilakukan melalui manipulasi biaya produksi, di mana perusahaan akan memiliki biaya produksi lebih tinggi daripada level normalnya. Estimasi nilai residu dari biaya produksi merupakan nilai abnormal PROD.

\section{Abnormal Discretionary Expenses (DISC)/Biaya Diskresionari Abnormal}

Abnormal discretionary expenses adalah manipulasi laba yang dilakukan melalui biaya penelitian dan pengembangan, biaya iklan, biaya penjualan, administrasi, dan umum. Estimasi nilai residu dari biaya diskresioner merupakan nilai abnormal DISC.

\section{Manajemen Laba Akrual}

Menurut Surifah (2001) dalam Wijayanti (2009:39-40) discretionary accrual (kebijakan akuntansi akrual) adalah suatu cara untuk mengurangi pelaporan laba yang sulit dideteksi melalui manipulasi kebijakan akuntansi yang berkaitan dengan akrual, misalnya dengan cara menaikkan biaya amortisasi dan depresiasi, mencatat kewajiban yang besar atas jaminan produk (garansi), kontijensi dan potongan harga, dan mencatat persediaan yang sudah usang.

Akrual merupakan semua kejadian yang bersifat operasional pada suatu tahun yang berpengaruh terhadap arus kas, perubahan piutang dan hutang, serta perubahan persediaan. Sedangkan untuk biaya depresiasi merupakan akrual negatif. Akuntan memperhitungkan akrual untuk menandingkan biaya dengan pendapatan melalui perlakuan transaksi yang berkaitan dengan laba bersih sesuai dengan yang diharapkan.

\section{Pengembangan Hipotesis}

Beberapa penelitian menunjukkan adanya manajemen laba pada perbankan syariah. Padmantyo (2010) menemukan adanya praktik manajemen laba pada Bank Syariah Mandiri dan Bank Muamalat yang diindikasikan dengan adanya total acrrual yang positif selama 4 tahun dan negatif selama 1 tahun sehingga terdapat manajemen laba pada laporan keuangan Bank Syariah Mandiri dan Bank Muamalat 
Indonesia selama 4 tahun. Trisnawati, dkk. (2010) melakukan penelitian earning management dengan pendekatan manajemen laba riil dan akrual pada perusahaan yang tergabung pada indeks JII dan LQ 45 dan menemukan bahwa perusahaan yang tergabung dalam indek syariah dan indeks konvensional Indonesia cenderung melakukan manajemen laba akrual dan riil dengan cara menaikkan angka laba. Faradila (2014) adanya manajemen laba yang diindikasikan dengan rata-rata accrual negative pada perbankan syariah di Indonesia.

H1a: Diduga terdapat Manajemen Laba pada Perbankan Syariah dengan melakukan manipulasi manajemen laba akrual

$\mathrm{H1b}$ : Diduga terdapat bank syariah dengan kinerja buruk melakukan manipulasi manajemen laba riil.

\section{METODE PENELITIAN}

\section{Lokasi dan Waktu Penelitian}

Penelitian ini dilakukan berdasarkan situs-situs atau web dari setiap bank yang termasuk Bank Umum Syariah yang terdapat di Indonesia. Peneliti memilih situs atau web tersebut langsung dari bank tersebut karena dianggap memiliki data yang lengkap dan telah terorganisasi dengan baik. Penelitian dilakukan dengan kurun waktu antara tahun 2010 sampai dengan tahun 2012.

\section{Metode Pengumpulan Data dan Analisis Data}

Pengumpulan data dilakukan melalui studi pustaka atau dokumentasi, yaitu pengambilan data yang diperoleh dari laporan keuangan publikasi bank syariah yang terdapat di Indonesia yang terkait untuk selanjutnya diolah oleh peneliti.

\section{Populasi dan Pengambilan Sampel}

Populasi penelitian ini adalah bank syariah yang terdapat di Bank Indonesia pada periode 2010 sampai dengan 2012. Teknik pengambilan sampel atau sampling adalah suatu proses penyeleksian terhadap beberapa elemen dari populasi untuk mendapatkan sampel yang diteliti. Pengambilan sampel penelitian untuk perbankan syariah dengan menggunakan purposive sampling yang memenuhi kriteria sebagai berikut: (1) Bank Umum Syariah yang mempunyai data yang lengkap, (2) Bank Umum Syariah yang mengeluarkan laporan keuangan 3 tahun berturut-turut, yaitu tahun 2010-2012 (3) Periode laporan keuangan berakhir pada 31 Desember pada tiap tahunnya. 


\section{Metode Analisis dan Pengukuran}

\section{Variabel Manajemen Laba Akrual}

Penghitungan total akrual sama dengan yang dilakukan Healy (1985) dan Jones (1991) dalam Zahara dan Siregar (2006) yang telah disesuaikan dengan karakteristik perbankan, dengan rumus:

$\mathrm{TA}_{\mathrm{it}}=\left(\Delta \mathrm{PMAD}_{\mathrm{it}}+\Delta \mathrm{BDD}_{\mathrm{it}}+\Delta \mathrm{UMP}_{\mathrm{it}}-\Delta \mathrm{BYD}_{\mathrm{it}}-\Delta \mathrm{UP}_{\mathrm{it}}-\mathrm{BAP}_{\mathrm{it}}-\mathrm{Dep}_{\mathrm{it}}\right) /\left(\mathrm{A}_{\mathrm{it}-1}\right)$

Dimana: $\mathrm{TA}_{\mathrm{it}}=$ total akrual bank syariah i pada tahun $\mathrm{t}, \triangle \mathrm{PMAD}_{\mathrm{it}}=$ selisih pendapatan masih akan diterima bank syariah i pada tahun $\mathrm{t}$ dengan $\mathrm{t}-1, \Delta \mathrm{BDD}_{\mathrm{it}}=$ selisih beban dibayar dimuka bank syariah i pada tahun t dengan $\mathrm{t}-1, \Delta \mathrm{UMP}_{\mathrm{it}}=$ selisih uang muka pajak bank syariah i pada tahun $\mathrm{t}$ dengan $\mathrm{t}-1, \Delta \mathrm{BYD}_{\mathrm{it}}=$ selisih beban yang harus dibayar bank syariah i pada tahun $\mathrm{t}$ dengan $\mathrm{t}-1, \Delta \mathrm{UP}_{\mathrm{it}}=$ selisih utang pajak bank syariah i pada tahun t dengan $\mathrm{t}-1, \mathrm{BAP}_{\mathrm{it}}=$ beban penyisihan

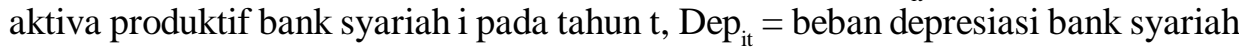
i pada tahun $\mathrm{t}, \mathrm{A}_{\mathrm{it}-1}=$ total aktiva bank syariah i pada tahun $\mathrm{t}-1$.

Kemudian, dilakukan estimasi dengan menggunakan model:

$\mathrm{TA}_{\mathrm{it}} / \mathrm{A}_{\mathrm{it}-1}=\mathrm{a}_{1}\left(1 / \mathrm{A}_{\mathrm{it}-1}\right)+\mathrm{b}_{1}\left(\Delta \mathrm{PO}_{\mathrm{it}} / \mathrm{A}_{\mathrm{it}-1}\right)+\mathrm{b}_{2}\left(\mathrm{PPE}_{\mathrm{it}} / \mathrm{A}_{\mathrm{it}-1}\right)+\varepsilon_{\mathrm{it}}$

Di mana: $\mathrm{TA}_{\mathrm{it}}=$ total akrual bank syariah i pada tahun $\mathrm{t}, \mathrm{A}_{\mathrm{it}-1}=$ total aktiva bank syariah i pada tahun $\mathrm{t}-1$, " $\mathrm{PO}_{\mathrm{it}}=$ selisih pendapatan operasi bank syariah i pada tahun $\mathrm{t}$ dengan $\mathrm{t}-1, \mathrm{PPE}_{\mathrm{it}}=$ property, plant, and equipment (aktiva tetap) bank syariah i pada tahun t. Perkiraan error $\left(\varepsilon_{\mathrm{it}}\right)$ dalam persamaan di atas menunjukkan akrual diskresioner (discretionary accrual).

\section{Variabel Manajemen Laba Riil}

Manajemen Laba riil dihitung dengan pendekatan yang digunakan Roychowdhury (2006) sebagai berikut:

\section{Abnormal CFO}

CFOt/At- $1=\alpha 0+\alpha 1($ A/At-1 $)+\alpha 2($ St $/$ At -1$)+\alpha 3(\Delta$ St $/$ At -1$)+\varepsilon t$

$\mathrm{CFO}=$ Cash Flow from operating activities (arus kas operasi) perusahaan I pada tahun $\mathrm{t}$

At-1 = Aset total perusahaan I tahun $\mathrm{t}-1$

St $=$ Penjualan total perusahaan I pada tahun $\mathrm{t}-1$

Untuk setiap observasi tahun, arus kas kegiatan operasi abnormal (ABN_CFO) adalah nilai residual dari estimasi model persamaan regresi di atas.

\section{Pengujian Hipotesis}

Pengujian Hipotesis 1a (H1a) diatas diuji degan mengikuti (Roychowdhury, 2006 dalam Hastuti, 2011) dengan persamaan sebagai berikut: 
$Y t=\beta 0+$ â1Suspect_NI+ $\beta 2 N i t+\beta 3 C L t+\varepsilon t$

Yt : Proksi-proksi manipulasi aktivitas riil (masing-masing abnormal arus kas kegiatan operasi, abnormal biaya produksi dan abnormal diskrestioner)

Suspect_NI : Variabel Indikator yaitu dengan nilai 1 untuk perusahaan suspect (perusahaan dengan laba/total aset bernilai 0-0,005, diasumsikan mempunyai motivasi melakukan manajemen laba riil karena kinerjanya buruk. Dan diberi nilai 0 untuk yang lain (non suspect).

NI : Laba sebelum Extra ordinary items dibagi total asset

CL : Kewajiban lancar dibagi dengan total asset

NI dan CL merupakan variable-variabel kontrol dengan pengambilan kesimpulan:

Untuk Yt = Abnormal CFO, jika $\beta 1$ bernilai negative signifikan maka perusahaan suspect melakukan manipulasi penjualan sehinga mempunyai abnormal cash flow kegiatan operasi yang lebih rendah dibanding perusahaan lain.

Pengujian Hipotesis 1 (H1b) diatas digunakan uji beda, yaitu rata-rata nilai AD pada bank syariah $\neq 0$

\section{HASIL PENELITIAN DAN PEMBAHASAN}

\section{Gambaran Sampel}

Populasi dalam penelitian ini merupakan bank syariah yang terdiri atas 11 bank. Tetapi dikarenakan beberapa data dari perbankan syariah tidak lengkap atau tidak dapat diskses maka sampel dalam penelitian ini hanya 7 bank.

\section{Deskripsi Temuan Penelitian}

\section{Statistik Deskriptif}

Tabel 1. Statistik Deskriptif

\begin{tabular}{llllll}
\hline & N & Minimun & Maximum & Mean & Std. deviasi \\
\hline $\begin{array}{l}\text { Acrual } \\
\begin{array}{l}\text { Discretioner } \\
\text { Abnormal cash }\end{array}\end{array}$ & 21 & $-9.7825 \mathrm{E}-11$ & $2.5388 \mathrm{E}-10$ & 0.000000 & 0.000000000080572 \\
flow & 21 & -0.73 & 2.01 & -0.0245 & $1.62152 \mathrm{E} 15$ \\
\hline
\end{tabular}

Berdasarkan data di atas berdasarkan tabel, dapat diketahui bahwa jumlah sampel yang diobservasi dalam penelitian ini sebanyak 21 bank syariah. Nilai minimum dari AD sebesar 1.06E-10 dan nilai rata-rata adalah -5.02E-12, nilai maksimumnya 1.142E-11 dan standar deviasinya 8.074627E-11. Sedangkan nilai abnormal cash flow menunjukkan nilai minimum -0.73 dan maximum 2.01 sedangkan nilai mean adalah -0.0245 . 
Nilai akrual diskretioner (AD) dan nilai abnormal cash flow yang sangat rendah (berkisar pada angka 0) menunjukkan adanya manajemen laba yang dilakukan bank syariah sangat rendah. Nilai akrual diskresioner yang berada di atas 0 menunjukkan bahwa metode manajemen laba yang dilakukan perusahaan adalah memperbesar laba. Sedangkan nilai akrual diskresioner yang berada di bawah 0 atau bernilai negatif menunjukkan bahwa metode manajemen laba yang dilakukan oleh perusahaan adalah memperkecil laba (Fatmawati dan Sabeni, 2013).

\section{Analisis Manajemen Laba Akrual}

\section{Accrual Discretionery di tahun 2010}

Berdasarkan oleh data statitistik dengan menggunakan rumus model jones yang yang dimodifikasi untuk perbankan maka diperoleh nilai residual error yang merupakan nilai akrual diskretioner (AD). Berikut nilai AD untuk masing-masing bank.

Tabel 2. Akrual Diskretioner Tahun 2010

\begin{tabular}{lc}
\hline \multicolumn{1}{c}{ Nama Bank } & Nilai Akrual Diskretioner (AD) \\
\hline Bank Panin Syariah & $-9.78252 \mathrm{E}-11$ \\
Bank Rakyat Indonesia Syariah & $-7.55153 \mathrm{E}-11$ \\
Bank Bukopin Syariah & $9.7252 \mathrm{E}-12$ \\
Bank Syariah Mand iri & $-9.47971 \mathrm{E}-11$ \\
Bank Mega Syariah & $-5.7968 \mathrm{E} 12$ \\
Bank Muamalat & $1.7889 \mathrm{E}-12$ \\
Bank Central Asia Syariah & $2.538880 \mathrm{E}-10$ \\
\hline
\end{tabular}

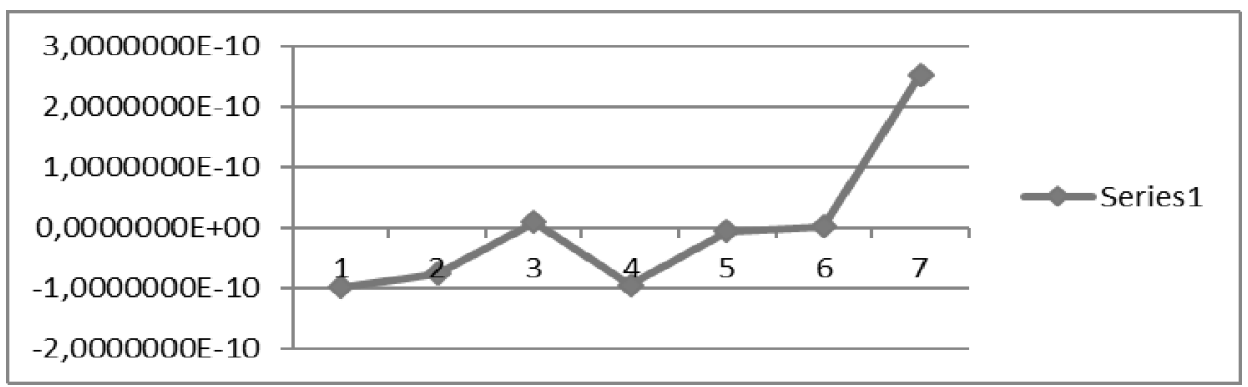

\section{Gambar 1. Grafik Akrual Diskretioner Tahun 2010}

\section{Keterangan:}

1. Bank Panin Syariah

2. BRI Syariah

3. Bank Bukopin

4. Bank Syariah Mandiri

5. Bank Mega Syariah

6. Bank Muamalat

7. BCA Syariah 
Tabel 2 menunjukkan terdapat 4 bank syariah pada tahun 2010 menunjukkan nilai Discretionary Accrual negatif dan 3bank syariah yang menunjukkan nilai Discretionary Accrual positif. Hal ini berarti 4 bank syariah tersebut melakukan manajemen laba dengan cara menurunkan laba dan 3 bank syariah melakukan manajemen laba dengan cara menaikkan laba.

Dari grafik 1 dapat dilihat nilai AD di tahun 2010 nilai minimum adalah -1.00E10 yang merupakan nilai AD dari Bank Syariah Mandiri, sedangkan nilai AD maksimum adalah sebesar 2.50E-10 yang merupakan nilai AD dari Bank BCA Syariah.

\section{Accrual Discretionery di Tahun 2011}

Tabel 3. Akrual Diskretioner Tahun 2011

\begin{tabular}{lc}
\hline \multicolumn{1}{c}{ Nama Bank } & Nilai Akrual Diskretioner(AD) \\
\hline Bank Panin Syariah & $-1.20258 \mathrm{E}-11$ \\
Bank Rak yat Indonesia Syariah & $-4.05624 \mathrm{E}-11$ \\
Bank Bukopin Syariah & $-2.69431 \mathrm{E}-11$ \\
Bank Syariah Mandiri & $-4.84428-11$ \\
Bank Mega Syariah & $-6.9923 \mathrm{E}-12$ \\
Bank Muamalat & $-3.90289 \mathrm{E}-12$ \\
Bank Central Asia Syariah & $1.326453 \mathrm{E}-10$ \\
\hline
\end{tabular}

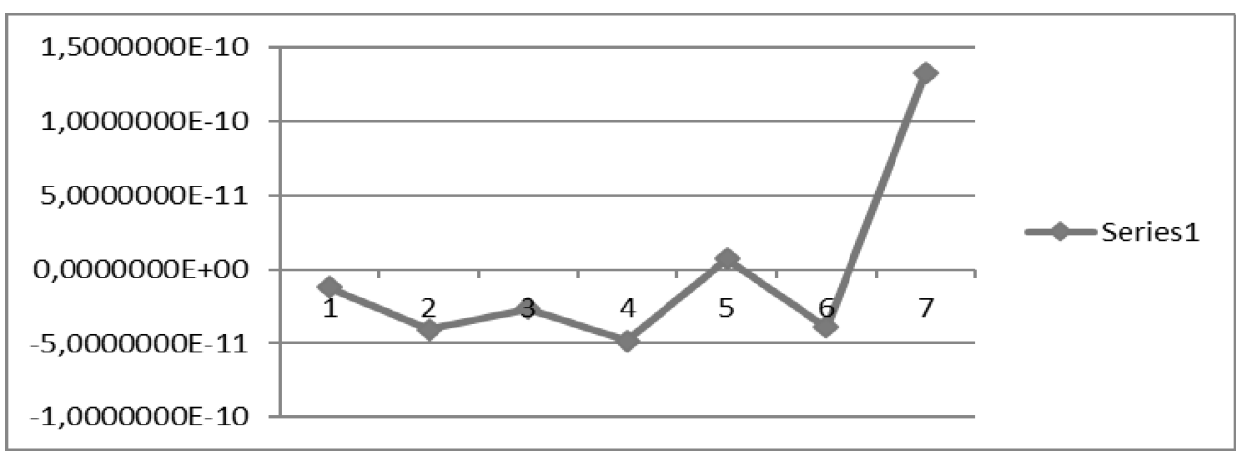

\section{Gambar 2. Akrual Diskretioner Tahun 2011}

Tabel 3 menunjukkan terdapat 6 Bank Syariah pada tahun 2011 menunjukkan nilai Discretionary Accrual negatif dan1 Bank Syariah yang menunjukkan nilai Discretionary Accrual positif. Hal ini berarti 6 bank syariah tersebut melakukan manajemen laba dengan cara menurunkan laba dan 1 bank syariah melakukan manajemen laba dengan cara menaikkan laba. 
Dari grafik 2 dapat dilihat nilai AD di tahun 2011 nilai minimum adalah -4.8442811 yang merupakan nilai AD dari Bank Syariah Mandiri, sedangkan nilai AD maksimum adalah sebesar 1.326453E-10 yang merupakan nilai AD dari Bank BCA syariah.

\section{Akrual Diskresioner di Tahun 2012}

Tabel 4. Akrual Diskresioner Tahun 2012

\begin{tabular}{lc}
\hline \multicolumn{1}{c}{ Nama Bank } & Nilai Akrual Diskretioner (AD) \\
\hline Bank Panin Syariah & $3.3284 \mathrm{E}-12$ \\
Bank Rakyat Indonesia Syariah & $-4.3694 \mathrm{E}-12$ \\
Bank Bukopin Syariah & $-2.33469 \mathrm{E}-12$ \\
Bank Syariah Mandiri & $-4.76072 \mathrm{E}-11$ \\
Bank Mega Syariah & $2.64866 \mathrm{E}-11$ \\
Bank Muamalat & $-3.03600 \mathrm{E}-11$ \\
Bank Central Asia Syariah & $1.117662 \mathrm{E}-10$ \\
\hline
\end{tabular}

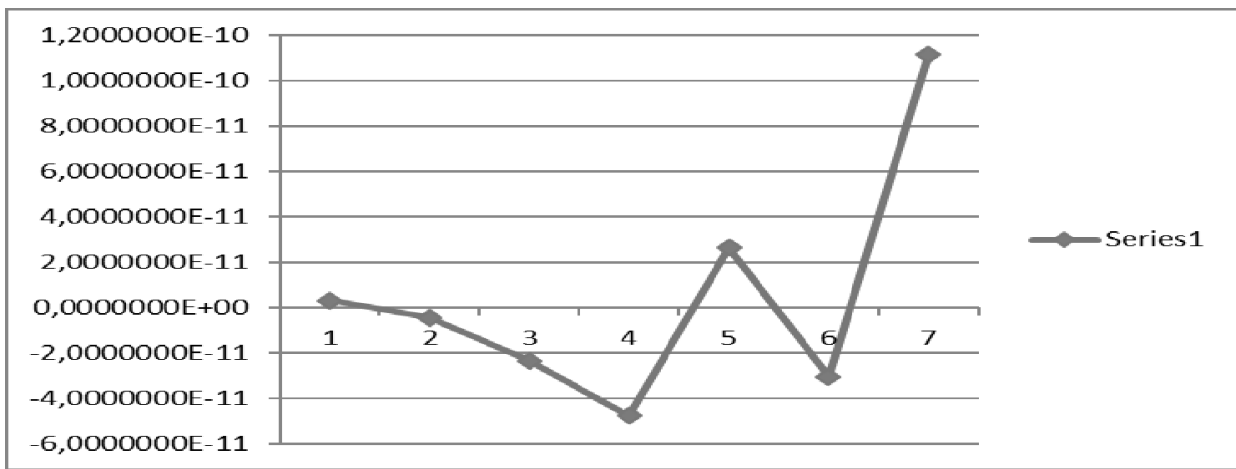

\section{Gambar 3. Akrual Diskretioner di Tahun 2012}

Tabel 4 menunjukkan terdapat 4 Bank Syariah pada tahun 2011 menunjukkan nilai Discretionary Accrual negatif dan 3 bank syariah yang menunjukkan nilai Discretionary Accrual positif. Hal ini berarti 4 bank syariah tersebut melakukan manajemen laba dengan cara menurunkan laba dan 3 bank syariah melakukan manajemen laba dengan cara menaikkan laba.

Dari grafik 3dapat dilihat nilai AD di tahun 2011 nilai minimum adalah -4.76072E-11 yang merupakan nilai AD dari Bank Syariah Mandiri, sedangkan nilai $\mathrm{AD}$ maksimum adalah sebesar $1.117662 \mathrm{E}-10$ yang merupakan nilai $\mathrm{AD}$ dari Bank BCA syariah. 


\section{Manajemen Laba Riil}

Tabel 5. Perusahaan Suscpect/Non Suspect Manajemen Laba

\begin{tabular}{|c|c|c|}
\hline Nama Bank & Laba/Total Asset & Keterangan \\
\hline \multicolumn{3}{|c|}{ Tahun 2010} \\
\hline Bank Panin & $(0.02391894)$ & Suspect \\
\hline BRI Syariah & 0.00132023 & Suspect \\
\hline Bank Bukopin & 0.00003229 & Suspect \\
\hline Bank Syariah Mandiri & 0.00001785 & Suspect \\
\hline Bank Mega Syariah & 0.01888337 & Non suspect \\
\hline Bank Muamalat & 0.01113410 & Non suspect \\
\hline BCA Syariah & 0.01010776 & Non suspect \\
\hline \multicolumn{3}{|c|}{ Tahun 2011} \\
\hline Bank Panin & 0.01209548 & Non suspect \\
\hline BRI Syariah & 0.00045273 & Suspect \\
\hline Bank Bukopin & 0.02872771 & Non suspect \\
\hline Bank Syariah mandiri & 0.01563165 & Non suspect \\
\hline Bank Mega syariah & 0.01360262 & Non suspect \\
\hline Bank Muamalat & 0.01181111 & Non suspect \\
\hline BCA Syariah & 0.00736550 & Non suspect \\
\hline \multicolumn{3}{|c|}{ Tahun 2012} \\
\hline Bank Panin & 0.02309712 & Non suspect \\
\hline BRI & 0.00930057 & Non suspect \\
\hline Bank Bukopin & 0.03060772 & Non suspect \\
\hline Bank Syariah mandiri & 0.02063887 & Non suspect \\
\hline Bank Mega syariah & 0.03102292 & Non suspect \\
\hline Bank Muamalat & 0.01169398 & Non suspect \\
\hline $\mathrm{BCA}$ & 0.00689327 & Non suspect \\
\hline
\end{tabular}

Berdasarkan Tabel 5diketemukan hanya 5 (lima) bank syariah yang suspect melakukan manajemen laba riil yaitu Bank Panin, BRI Syariah, Bukopin, BSM, Bank Mega Syariah di tahun 2010 dan BRI Syariah di tahun 2011. Sedangkan bank lainnya tidak termasuk suspect. Perusahaan suspect merupakan perusahaan dengan kinerja yang buruk diukur dari laba/total asset bernilai 0-0,005). 
Tabel 6. Hasil Uji Statistik

\begin{tabular}{|c|c|c|c|c|c|c|}
\hline \multicolumn{7}{|c|}{ Coefficients $s^{a}$} \\
\hline & & Unstandardized & Coefficients & $\begin{array}{c}\text { Standardized } \\
\text { Coefficients }\end{array}$ & & \\
\hline \multicolumn{2}{|c|}{ Model } & B & Std. Error & Beta & $\mathbf{t}$ & Sig. \\
\hline \multirow[t]{4}{*}{1} & (Constant) & -.435 & .287 & & -1.513 & .149 \\
\hline & $\mathrm{x} 1$ & .283 & .482 & .124 & .588 & .564 \\
\hline & $\mathrm{x} 2$ & 2.293E-12 & .000 & .682 & 2.616 & .018 \\
\hline & $\mathrm{x} 3$ & $-3.120 \mathrm{E}-16$ & .000 & -.509 & -1.939 & .069 \\
\hline
\end{tabular}

a. Dependent Variable: $y$

Analisis laba Riil dengan mengukur abnormalcash flow menunjukkan nilai meansebesar -0.0245 menunjukkan terdapat manajemen laba pada perbankan syariah dengan cara menurunkan laba. Dan nilai $\beta 1$ bernilai positif 0.283 dan sig 0.564 menunjukkan bahwa perusahaan suspect tidak melakukan manajemen laba dengan cara manipulasi operating cash flow, jadi dapat disimpulkan bahwa H1b ditolak.

\section{PEMBAHASAN}

\section{Manajemen Laba Akrual}

Hasil nilai AD pada perbankan syariah yang berkisar pada nilai nol menunjukkan bahwa manajemen laba akrual yang dilakukan diperbankan syariah masih sangat rendah. Hal ini konsisten dengan penelitian yang dilakukan oleh Koosrini (2010), Padmantyo (2010) dan Faradila (2014). Kemungkinan nilai AD negatif yang meningkat dari tahun 2011 ke tahun 2014 manajer melakukan manajemen laba dengan cara menurnukan laba pada tahun 2011 dan 2012 dengan tujuan untuk menurunkan beban pajak yang harus dibayar oleh perusahaan. Hal ini dikarenakan Pemerintah menerbitkan dua peraturan mengenai pengenaan pajak penghasilan atas kegiatan usaha pembiayaan syariah dan perbankan syariah.

Peraturan pertama ialah perlakuan pajak atas kegiatan sewa guna usaha yang dilakukan berdasarkan Ijarah diperlakukan sama dengan kegiatan sewa guna usaha tanpa hak opsi (operating lease), sewa guna usaha Ijarah Muntahiyah Bittamlik diperlakukan sama dengan sewa guna usaha dengan hak opsi (financial lease), kegiatan usaha anjak piutang Wakalah bil Ujrah danpembiayaan konsumen berdasarkan akad Murabahah, Salam, dan Istishna yang keuntungannya dikenai pajak penghasilan sesuai dengan ketentuan pajak penghasilan atas bunga, serta penghasilan yang diterima dari kegiatan usaha kartu kredit dan pembiayaan berdasarkan prinsip syariah lainnya, dikenakan pajak penghasilan sesuai dengan ketentuan dalam UndangUndang Pajak Penghasilan (PPh). Hal itu tercantum dalam Peraturan Menteri 
Keuangan Nomor 136/PMK.03/2011 tentang Pengenaan Pajak Penghasilan untuk Kegiatan Usaha Pembiayaan Syariah. Peraturan kedua yang dikeluarkan pemerintah adalah mengenai kegiatan usaha perbankan syariah, penghasilan berupa bonus, bagi hasil, margin keuntungan dikenakan pajak penghasilan sesuai ketentuan pengenaan pajak penghasilan atas bunga, serta pembebanan biaya untuk kegiatan pembiayaan syariah dan perbankan syariah mengacu pada ketentuan UU PPh. Apabila terdapat pengalihan harta atau sewa harta yang wajib dilakukan untuk memenuhi prinsip syariah, maka tidak termasuk dalam pengertian pengalihan harta sebagaimana dalam UU PPh. Peraturan kedua ini sebagaimana tertera dalam Peraturan Menteri Keuangan Nomor 137/PMK.03/2011 tentang Pengenaan Pajak Penghasilan untuk Kegiatan Usaha Perbankan Syariah. Pemerintah mengeluarkan peraturan tersebut agar akan ada keselarasan penerapan peraturan perpajakan dengan praktik kegiatan usaha berdasarkan prinsip syariah.

\section{SIMPULAN}

Penelitian ini bertujuan untuk menguji dan menganalisis manajemen laba terhadap perbankan syariah dengan analisis akrual dan riil. Berdasarkan pengujianpengujian yang telah dilakukan selama periode pengamatan, maka hasil penellitian dapat disimpulkan:Pertama, bank syariah melakukan manajemen laba dalam laporan keuangan. Hal ini dibuktikan dengan hasil Discretionary Accrual selama tiga tahun yang bernilai positif dan negatif. Dengan nilai mean -5.08E-25 mengindikasikan bahwa nilai mean yang masih berkisar nol maka dapat ditarik kesimpulan bahwa manajemen laba yang dilakukan bank syariah sangat rendah. Kedua, analisis manajemen laba riil dengan mengukur abnormal cash flow menunjukkan nilai mean sebesar -0.0245menunjukkan bahwa ada manajemen laba dengan cara menurunkan laba dan $\beta 1$ bernilai positif 0.283 dan sig 0.564 menunjukkan bahwa perusahaan suspect tidak melakukan manajemen laba dengan cara memanipulasi operating cash flow.

Penelitian ini mempunyai keterbatasan dan belum sempurna sehingga hal ini dapat dijadikan rekomendasi di masa yang akan datang. Keterbatasan penelitian ini adalah sampel dalam penelitian ini masih sedikit hanya 7 Bank Umum Syariah sehingga kurang dapat mewakili semua bank syariah yang ada di Indonesia sehingga untuk penelitian selanjutnya diharapkan dapat menambah sampel penelitian. Pengukuran manajemen laba riil hanya menggunakan pengukuran abnormal cash flow. Diharapkan penelitian selanjutnya menggunakan proksi tambahan yang lain misalnya abnormal production cost dan abnormal discretionary expenseyang disesuaikan untuk perbankan.

Saran dari penelitian ini adalah untuk perbankan syariah sebaiknya tidak melakukan manajemen laba dalam laporan keuangan karena dapat merugikan para pembaca laporan keuangan karena informasi yang disampaikan menjadi tidak akurat 
dan tidak menggambarkan keadaan perusahaan yang sebenarnya. Adanya manajemen laba dalam perbankan syariah.

\section{DAFTAR PUSTAKA}

Faradila, A. 2014. Analisis Manajemen Laba pada Perbankan Syariah. Jurnal Riset Akuntansi Keuangan dan Komputerisasi Akuntansi. Vol 4, No.1 Februari 2013.

Hastuti, S. 2011. Titik Kritis ManajemenpadaTahap Life Cycle. Jurnal Akuntansi dan Keuangan Indonesia Vol. 8, No. 2.

IAI. 2009. Standar Akuntansi Keuangan Syariah. Salemba Empat.

IAI. 2009. Standar Akuntansi Keuangan. Salemba Empat.

Padmantyo, S. 2010. Analisis Manajemen Laba Pada Laporan Keuangan Perbankan Syariah (Studi Pada Bank Syariah Mandiri dan Bank Muamalat Indonesia). BENEFIT Jurnal Manajemen dan Bisnis Vol. 14, No. 2, Desember 2010, hlm. 53-65.

Pramudji, T. 2010. Pengaruh Independensi dan Efektivitas Komite Audit terhadap Manajemen Laba (Studi Empiris pada Perusahaan manufaktur yang Terdaftar di BEI. Jurnal Dinamika Akuntansi Vol. 2.

Ratmono, D. 2010. Manajemen Laba Riil dan Akrual dapatkan Aduitor Ekstern Mendeteksinya. Simposium Nasional Akuntansi XIII Purwokerto.

Scott. 1997. Financial Accounting Theory. USA: Prentice-Hall.

Setiawati, K. 2010. Pengaruh Rasio Camel terhadap Manajemen Laba pada Perbankan Syariah. UNDIP Skripsi Belum dipublikasikan.

Subekti, I., Kee, P.L., dan Ahmad, Z. 2010. The Effect of Integrated Earnings Management on The Value Relevance of Earnings And Book Value of Equity. Kumpulan artikel Simposium Nasional Akuntansi (SNA) XIII. Purwokerto.

Trisnawati, R., dkk. 2012. Pengukuran Manajemen Laba: Pendekatan Terintegrasi (Studi Komparasi Perusahaan Manufakur yang Tergabung PadaIndeks JII dan LQ-45 Bursa Efek Indonesia Periode 2004-2010). Http. Publikasi Ilmiah.ums.ac. Diakses pada 12 Februari 2013.

Zahara dan Sylvia, V.S. 2007. Pengaruh Rasio Camel terhadap Praktik Manajemen Laba di Bank Syariah. Jakarta: Ikatan Akuntan Indonesia Kompartemen Akuntan Pendidik. 